\title{
9
}

\section{Engaging with 'The Everyday': Towards a More Dynamic Conception of Hybrid Transitional Justice}

\author{
Lia Kent
}

\section{Introduction}

Just as critical peacebuilding scholars are increasingly engaging with the concept of hybridity, so too are scholars working in the closely related field of transitional justice, ${ }^{1}$ which is concerned with the mechanisms and practices used by states, communities and individuals to address the legacies of violent conflict. A clear manifestation of this is the growing number of studies that consider the potential of local or customary dispute resolution practices to help deliver justice to victims and promote reconciliation. In Timor-Leste, for instance, the local dispute resolution practice known as nahe biti (literally, 'stretching the mat') has received a great deal of scholarly attention, particularly since aspects of this practice were incorporated into the nationwide community reconciliation process that was implemented by the Commission for Reception, Truth and

1 Transitional justice is a rapidly expanding field of scholarship and practice. It is concerned with a broad range of measures such as criminal trials, truth commissions, reparations policies, institutional reform, lustration (the vetting of public officials), memorialisation and reforms to police, prisons and the judiciary. 
Reconciliation. ${ }^{2}$ There has been similar interest in the Sierra Leone Truth Commission, which was authorised to involve traditional and religious leaders in its hearings, and Rwanda's gacaca courts, which saw the transformation of local dispute resolution practices into a nationwide system for resolving cases of serious crimes. ${ }^{3}$

While I recognise the value of these analyses, the starting point of this chapter is that more attention is needed to the ways in which individuals and communities deal with the legacies of conflict outside formal institutional contexts and dispute resolution forums. I draw here on my observations of Timor-Leste, where the legacies of the 24-year Indonesian occupation continue to reverberate and where people often appear to be negotiating them through subtle actions, practices and tactics that do not involve direct forms of confrontation between perpetrators and victims. ${ }^{4}$ In this chapter, I aim to draw out some of these practices and tactics that, I suggest, are critical to the ongoing process of reconstructing social life in the wake of the occupation, and which might be understood as part of a process of ongoing, 'everyday' reconciliation. I use the term 'everyday reconciliation' to describe the ways in which individuals, families and communities are seeking to resume patterns of communication, exchange and sociality, resist threats to their existence and wellbeing, and exert a degree of control over their lives. Building on my observations of the Timor-Leste context, I explore the potential of the concept of the everyday - and everyday reconciliation - to widen the scope of what tends to be encompassed in analyses of hybrid transitional justice.

In essence, what I am proposing here is the need for a richer, more dynamic, conception of hybrid transitional justice that goes beyond a focus on institutions, structures and dispute resolution 'events' and pays more attention to the ongoing process of rebuilding everyday life, and renegotiating relationships, in the wake of conflict. Central to this

2 For example, see Braithwaite et al., 'Transitional Justice and Reconciliation'; Kent, 'Community Views of Justice and Reconciliation in Timor-Leste'; Larke, ““... And the Truth Shall Set You Free”; Zifcak, 'Restorative Justice in Timor-Leste'.

3 Waldorf, 'Mass Justice for Mass Atrocity', 3-4. This interest dovetails with developments in the policy sphere. For example, two key United Nations reports acknowledged the significance of indigenous and informal traditions for administering justice. These were the 2004 report of then UN Secretary General Kofi Annan, titled The Rule of Law and Transitional Justice in Conflict and Postconflict Societies, and the 2011 report of the same name by UN Secretary General Ban Ki Moon.

4 This process included a truth commission-the Commission for Reception, Truth and Reconciliation_ and a 'hybrid' or internationalised tribunal known as the Special Panels for Serious Crimes that prosecuted cases of 'serious crimes'. 
conception is the recognition (that has long been a feature of feminist thinking and the work of anthropologists) that individuals are not isolated, independent, entities but are 'socially constituted bodies, attached to others. 5 The dynamic conception of hybrid transitional justice that I propose is informed, then, by a relational understanding of selves as integrally connected to others. This understanding is particularly salient in the context of kinship-based societies, where maintaining good relations with one's kin is not only important to one's social standing, but is also essential to viable social life, security and economic survival.

This chapter proceeds in three parts. Part one provides a brief discussion of the concept of the everyday as it is being used within the peacebuilding literature before considering why, despite some take-up, it remains relatively neglected within the transitional justice scholarship. Part two draws out several practices and tactics of everyday reconciliation in Timor-Leste and explores their significance with reference to Audra Mitchell's concepts of 'worldbuilding' and 'threatworks'. ${ }^{6}$ The third part offers some thoughts on how greater attention to the everyday could enrich scholarship on hybrid transitional justice. What I aim to emphasise here is not that the current interest in local dispute resolution practices should be abandoned, but that, by situating these practices in the realm of the everyday, it is possible to imagine transitional justice as a far richer-more dynamic, ongoing and relational-process. What should also become clear is that, while my understandings of the everyday are informed by the insights of critical peacebuilding scholars, many of whom highlight the everyday as a site of resistance, I argue that more attention is needed to the everyday as a site where those with limited power 'make do' with the resources, tactics and possibilities at hand.

\section{Peacebuilding, transitional justice and the everyday}

The term 'everyday' evokes the quotidian, the routine, the familiar, a sense of ordinariness, repetition and stability. ${ }^{7}$ Yet, for conflict-affected societies, these aspects of everyday life cannot necessarily be taken for granted.

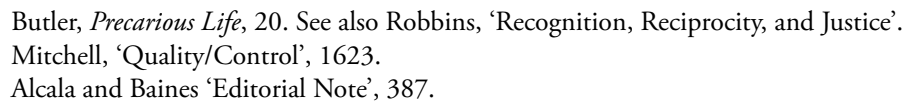


Rather than being a space of security and comfort, the everyday might appear as 'bristling with dangers'. ${ }^{8}$ These realities call for an understanding of the everyday as dynamic rather than stable, as a lively space in which emotions, interactions, tensions, power struggles, tactics of domination and resistance and small and big ceremonial routine events occur'. 'They also suggest the need for a recognition of the significant effort or labour that is required by those living in conflict-affected societies to achieve some measure of stability and routine in everyday life. ${ }^{10}$

In recent years, critical peacebuilding scholars have begun to engage with the everyday in this dynamic sense of the word, as part of a broader critique of, and response to, the limitations of liberal peacebuilding. ${ }^{11}$ Particularly illuminating are the insights of Audra Mitchell, who describes the everyday as the 'set of experiences, practices and interpretations through which people engage with the daily challenges of occupying, preserving, altering and sustaining the plural worlds that they occupy.'. Such practices, which Mitchell describes as 'worldbuilding, ${ }^{13}$ tend to be oriented towards the meeting of daily challenges, such as interacting with or caring for family members, friends and community, working, and exchanging goods. ${ }^{14}$ They may include the celebration of traditional holidays or the resumption of patterns of communication and exchange. ${ }^{15}$ They also comprise 'threatworks', a set of 'practices, institutions and customs' that are used by a range of different actors to 'exchange, acknowledge, evade, manoeuvre, contest and otherwise resist' perceived threats to their existence. ${ }^{16}$ Examples of threatworks include the erection of barriers or walls or the ostracism or segregation of particular members of the community. ${ }^{17}$ As Mitchell notes, threatworks are perceived by the actors involved as integral to maintaining their quality of life and some

8 Das, 'What Does Ordinary Ethics Look Like?'.

$9 \quad$ Alcala and Baines, 'Editorial Note', 387.

10 See Ross, Raw Life, New Hope, 70. See also Das, Life and Words.

11 See, for example, Mac Ginty 'Everyday Peace: Bottom-Up and Local Agency in Conflict-Affected Societies'; Mitchell, 'Quality/Control', 1623; Richmond, 'A Post-liberal Peace', 557; Richmond and Mitchell, 'Introduction-Towards a Post-liberal Peace', 1.

12 Mitchell, 'Quality/Control', 1624.

13 Mitchell uses the term 'world' not to refer to the 'terrestrial earth but rather to refer to the unique spaces in which human groups create and sustain their collective lives, interacting with their material environment'. Ibid, 1624.

14 Mitchell 'Quality/Control', 1625.

15 Ibid.

16 Ibid., 1641.

17 Ibid. 
form of control over it. ${ }^{18}$ Threatworks also have an important relationship to violence, in many cases playing a role in preventing and controlling cycles of violence. ${ }^{19}$

The work of Michel de Certeau exerts a prominent influence in this scholarship, in particular, his 1984 book, The Practice of Everyday Life. ${ }^{20}$ Here, de Certeau highlights the ways in which seemingly ordinary practices such as walking and dwelling can be central to the ways that individuals navigate societal control of their actions. De Certeau describes these practices as 'tactics' through which individuals attempt to carve out spaces for themselves while taking into account the institutions of power. ${ }^{21}$ This term is an attempt to capture the way in which, despite official plans, goals and visions, individuals can create alternative visions, contest these plans or negotiate around them, by using the subtle, flexible and resourceful tactics at their disposal. ${ }^{22}$ Central to de Certeau's work is the distinction between 'tactics' and 'strategies'. While strategies imply 'concerted action, enabled by rules, order and control over production, towards desired goals', tactics 'have a quality of flexibility to the immediate contexts'. ${ }^{23}$ Tactics tend to be subtle and small, and are often shifting and transient as they must 'seize on the wing the possibilities that offer themselves at any given moment'. ${ }^{24}$ What this distinction makes clear, then, is that strategies are the domain of the powerful, while tactics are the art of the less powerful. ${ }^{25}$

Building on de Certeau's insights, much of the scholarship on everyday peace is interested in the everyday as a site of resistance to liberal interventions and/or as an alternative site of knowledge for peacebuilding. ${ }^{26}$ Understood in this way, the everyday, like the closely related concept of hybridity, provides an important corrective to the 'technocratic turn' that characterises the study and practice of peacebuilding, by bringing to the fore the role of local knowledge and agency in grounding the legitimacy of

\footnotetext{
18 Ibid.

19 Ibid., 1642.

20 de Certeau, The Practice of Everyday Life.

21 Ibid, xi.

22 Richmond and Mitchell, 'Introduction-Towards a Post-liberal Peace', 16.

23 Ross, Raw Life, New Hope, 124.

24 de Certeau, The Practice of Everyday Life, 37. See also Vinthagen and Johansson, "'Everyday Resistance"', 17.

25 de Certeau, The Practice of Everyday Life, 37.

26 See Richmond, 'A Post-liberal Peace', 571.
} 
the peace. ${ }^{27}$ This scholarship is also increasingly attuned to what Mitchell refers to as 'deep ambiguity of everyday life'. ${ }^{28}$ What she means by this is that there is a growing recognition that the everyday is not only a 'space of resistance, agency, transcendence and the enhancement of life' but is also vulnerable to control, domination and manipulation by powerful external actors, both domestic and international..$^{29}$

Another increasingly recognised set of ambiguities relates to the acknowledgement of the everyday both as a source of agency, meaning, security and belonging and as a site where inequalities and hierarchies can be reinforced, and where violence can be 'embraced and reproduced'. ${ }^{30}$ This recognition is informed by a growing awareness of the diffuse, dispersed, complex and plural ways in which power operates and the extent to which any society is infused by multiple systems of hierarchy. ${ }^{31}$ This, in turn, is fostering greater awareness of the ways in which 'individuals can be simultaneously positioned as powerful and powerless' in the context of different relational configurations. ${ }^{32}$

As the fields of critical peacebuilding and transitional justice increasingly intersect, it is not surprising that transitional justice scholars are also engaging with the concept of the everyday. Among the first to use the concept were South African scholars, who deployed the everyday as a critical tool to explore the ways in which discourses and practices of justice and reconciliation had silenced and de-historicised structural violence. ${ }^{33}$ Many were inspired by the work of Njabulo Nbebele, whose 1984 series of essays, The Rediscovery of the Ordinary, called on South African writers to reorient their focus away from the 'spectacular' and monstrous aspects of life under apartheid to the 'ordinary'. ${ }^{34}$ Heeding this call, these scholars began to illustrate the ways in which everyday life in South Africa remains marked by the racism, poverty and inequalities of the apartheid era, despite the Truth and Reconciliation Commission's efforts to mark a definitive break between the past and the present.

\footnotetext{
27 Mac Ginty, 'Everyday Peace', 551.

28 Mitchell, 'Quality/Control', 1630.

29 Ibid., 1630, 1632.

30 Alcala and Baines, 'Editorial Note', 388.

31 Vinthagen and Johansson, “"Everyday Resistance”, 14, 26, 31.

32 Ibid., 31.

33 See Gready, The Era of Transitional Justice; Grunebaum, Memorializing the Past; Ross, Bearing Witness.

34 Nbebele, 'The Rediscovery of the Ordinary'.
} 
Beyond the South African context, an increasing number of transitional justice scholars are calling for more attention to everyday reconciliation or social repair. Among them are Alcala and Baines, who describe everyday social repair as:

the myriad ways in which people pursue mundane activities and practices to restore the basic fabrics of meaningful social relations, negotiate or recreate protective mechanisms and provide some sense of continuity in their lives and sense of self in relation to others. ${ }^{35}$

In contrast to the conventional way in which the concept of reconciliation is treated in the transitional justice scholarship-to refer to 'resolution, remission or relief ${ }^{36}$ - scholars interested in everyday reconciliation recognise the open-ended, partial and situated nature of this ongoing process. $^{37}$ To put this slightly differently, reconciliation is viewed in agonistic terms; it is seen as a 'difficult, restless and unceasing negotiation' ${ }^{38}$ rather than as a 'linear movement towards a harmonious end'. ${ }^{39}$ This open-ended conception allows for a consideration of the everyday ways in which adversaries interact without necessarily being motivated by a commitment to forgiveness. It also enables attention to the structural inequalities and constraints that impede the ability of those living in socalled 'postconflict' societies to draw a bright line between the past and the present. Collectively, this scholarship helps to capture the dynamic dimensions of reconciliation, and its precarious, nonlinear nature.

Despite this burgeoning interest, the everyday remains a relatively neglected concept in the transitional justice scholarship, even among those scholars interested in hybridity. One of the reasons for this is that transitional justice scholars and practitioners (like their peacebuilding counterparts) remain preoccupied with prescriptive as opposed to descriptive approaches to hybridity. ${ }^{40}$ There is, for instance, a tendency for scholars to be concerned with how local practices and rituals with sociocultural significance might be incorporated into-and enhance the legitimacy of - national-level transitional justice processes. ${ }^{41}$ While such

35 Alcala and Baines, 'Editorial Note', 386.

36 Williams, 'Reproducing Everyday Peace in North India', 233; see also Ring, Zenana.

37 Eastmond, 'Introduction: Reconciliation, Reconstruction and Everyday Life', 3.

38 Norval, 'Memory, Identity and the (Im)possibility of Reconciliation', 251.

39 Eastmond, 'Introduction', 5-10.

40 The terms 'descriptive' and 'prescriptive' hybridity were coined by Gearoid Millar. See Millar, 'Disaggregating Hybridity'.

41 Baines, 'Spirits and Social Reconstruction after Mass Violence', 416-417. 
efforts are valid, and important, what they tend to miss is close attention to the ways in which local practices and strategies unfold in their own right ${ }^{42}$ may vary markedly across different social and geographic settings and continuously evolve in response to changing contexts, circumstances and dynamics.

Perhaps the key reason for the neglect of the everyday is that the transitional justice field remains dominated by legal and political science scholars who are focused on institutions and are interested in normative questions. This leads to a gravitation towards local practices that are recognisably 'law like', such as customary dispute resolution practices, ${ }^{43}$ that appear to be oriented towards the 'resolution' of conflict. What tends to be left out of the analysis is the range of seemingly mundane ongoing everyday practices, negotiations and activities that may seem, at first blush, to have little to do with dispute resolution.

Contributing to this bias is the fact that customary dispute resolution practices are far easier for scholars to 'see' than everyday reconciliation tactics, which are by their nature fluid, shifting and subtle, and as such inherently difficult to study. As Mac Ginty notes, sophisticated methodological tools are required to capture something that 'passes by, passes through'. ${ }^{44}$ What is more, accessing the domain of the everyday can be difficult, and requires long-term engagement with research sites and language competence. It can also be ethically fraught, particularly if researchers seek to expose precarious coping strategies to public view. All of this serves to highlight the myriad practical, ethical and methodological challenges to studying the everyday.

\section{Everyday reconciliation in Timor-Leste}

The dynamic, social and relational dimensions of everyday reconciliation are starkly apparent in Timor-Leste. While it is now 15 years since the nation gained its formal independence and 10 years since the formal transitional justice mechanisms established by the United Nations (UN) reached the end of their formal mandates, the effects of the Indonesian

\footnotetext{
42 Ibid.

43 Waldorf, 'Local Transitional Justice', 158.

44 Mac Ginty, 'Everyday Peace: Bottom-Up and Local Agency', 550, quoting Seigworth and Gardiner, 'Rethinking Everyday Life', 140.
} 
occupation continue to reverberate in everyday life for many East Timorese. An obvious barrier to 'closure' is the continuing impunity of senior members of the Indonesian military; despite some prosecutions of East Timorese perpetrators, those living in Indonesia were out of the jurisdiction of the UN-sponsored Special Panels for Serious Crimes and remain out of reach of Timor-Leste's fledgling domestic legal system. Compounding these difficulties is the fact that the transitional justice mechanisms had short-term mandates, a limited temporal focus (the postreferendum 1999 violence), and were oriented towards a particular set of identities and relationships (that is, the relationship between 'victims' and 'perpetrators'). This has restricted their ability to address many of the complicated and enduring legacies of distrust and betrayal that have seeped into local communities and families.

These legacies of distrust are a reflection, in part, of the multiple roles many East Timorese played within the coercive context of the 24-year Indonesian occupation, which included, at different times, forms of both resistance and collaboration. It is well known that during the occupation the heavily militarised Indonesian state co-opted individuals into its security and administrative apparatus at all levels and developed an intricate systems of spies and informers, fostering fear and suspicion. ${ }^{45}$ In this coercive and corrosive context, neighbours and family members often denounced others as belonging to the resistance in part to protect themselves from being similarly denounced or as part of a dynamic of revenge/settling scores in relation to much older conflicts. Others infiltrated the military in order to assist the resistance. ${ }^{46}$ Many 'played both sides', at times working for the resistance and at other times collaborating with the regime, in an effort to 'enhance their own power' or in a desperate attempt to protect themselves and their relatives from harm. ${ }^{47}$ Elizabeth Drexler refers to these complex legacies as 'fatal knowledges', 'the particular knowledge that people have of past betrayal and complicity'. ${ }^{48}$ Fatal knowledges, she suggests, 'are not inert facts but rather dynamic performances of knowing or not knowing. ${ }^{49}$ They might be seen as embodied knowledge of the past

45 See Robinson, 'If You Leave Us Here We Will Die'; see also Larke “.... And the Truth Shall Set You Free"'.

46 Drexler, 'Fatal Knowledges', 76.

47 Ibid., 75.

48 Ibid., 92.

49 Ibid., 92. 
that can, at any time, be re-animated in the present. ${ }^{50}$ In this sense, they continue to pose powerful obstacles to peoples' efforts to rebuild ordinary lives and re-establish relationships.

Against this backdrop, people do the best they can to engage in forms of everyday reconciliation that might help to improve their lives, their economic circumstances and their relationships with their extended families and communities. These practices, negotiations, rituals and acts of everyday reconciliation resonate with Mitchell's concepts of 'worldbuilding' and 'threatworks' in that they are indicative of the ways in which individuals, families and communities are seeking to resume patterns of communication, exchange and sociality, as well as resist threats to their existence and exert a degree of control over their lives.

One example of an everyday reconciliation tactic can be seen in the ways in which those living in both rural and urban communities have been slowly reintegrating those who had fled, or were forced, across the border to Indonesian West Timor after the 1999 referendum. Around 200,000 East Timorese people are thought to have been displaced from TimorLeste at that time, many at the behest of pro-Indonesian East Timorese militia groups. These groups, which had been armed and trained by the Indonesian military, wreaked a trail of destruction after the referendum, looting and burning houses, and killing more than 1,000 people.

During the period of UN administration of the territory, a formal repatriation program was initiated by the United Nations Transitional Authority in East Timor, in coordination with the United Nations High Commissioner for Refugees and the International Organization for Migration, and refugee returns peaked just prior to Timor-Leste gaining formal independence in May 2002..$^{51}$ Since then, a 'small but steady stream' of East Timorese continue to informally and voluntarily return to their home. ${ }^{52}$ Due to a complex mix of factors, including the state's need to focus on building diplomatic relations with Indonesia, and the fact that these East Timorese are no longer classified as refugees but are recognised as new citizens of Indonesia, those seeking to return receive

50 See Das, 'What Does Ordinary Ethics Look Like?', 2.

51 Myat Thu, 'Displacement and Informal Repatriation in a Rural Timorese Village', 255.

52 Ibid. 
little or no assistance from the state. ${ }^{53}$ As a consequence, many return illegally, offering bribes to border patrol officers or taking risky paths along jalan tikus (goat tracks) to avoid the attention of the authorities. ${ }^{54}$

Given their extended absence from their communities, perceptions of their dubious pro-Indonesian associations, and the significant financial, social and political implication $s^{55}$ that are entailed in uprooting lives once again, it is common for potential returnees to make multiple visits to their communities over a period of years before definitively returning. During these visits, people participate in family rituals such as weddings and funerals, and investigate the status of their land and their prospects for economic survival. Their embodied presence in their communities seems to act as a form of communication in itself-a sign that they have not cut links with their homeland-and as a 'testing of the waters' as to whether their return would be welcomed.

In the small number of communities I have visited where returnees have recently arrived, a number of informal practices are occurring, which are suggestive of the ways in which dispersed families are seeking to re-establish ties. For instance, the participation of families in everyday activities such as church services, and the resumption of farming, appears to be a sign that they are welcomed, or at least tolerated. Other signs of welcome include the donation by village chiefs of rice and other provisions to returnees, and assistance by members of extended families in the rebuilding of the returnees' houses or uma luliks (sacred houses). Ritualised practices, involving the slaughter of animals and family feasts, are also taking place at uma luliks and at returnees' homes. These practices indicate the significance, for returnees, of remaking ties not only with living kin but with the ancestors, and the land with which they are integrally connected. Collectively, these practices demonstrate how returnees and their extended families seek to re-establish webs of connection and repair frayed kinship networks.

53 According to the International Crisis Group, those who chose not to participate in formal repatriation programs by 2002 were registered as Indonesian citizens. International Crisis Group, Timor-Leste: Reconciliation and Return from Indonesia, 3.

54 Myat Thu, 'Displacement and Informal Repatriation', 256.

55 For instance, returnees must relinquish their Indonesian citizenship upon returning to TimorLeste. 
Closely related to practices of reintegration are practices of social exclusion and shunning. It is interesting to observe that, just as some families are returning from West Timor, many others are not. While it is difficult to obtain firm figures, some suggest that the population of East Timorese in West Timor currently sits at around 100,000 people. ${ }^{56}$ Damaledo refers to members of this group as those who are 'guilty by association' because, while the majority were not members of pro-Indonesian militia groups, the Indonesian police force or the military, they comprise family members and relatives of militias and the Indonesian security forces, and thus are vulnerable to incrimination. ${ }^{57}$

Some East Timorese who do seek to return are not welcomed. A prominent example is the case of Martinus Bere, a former member of a Suai-based militia group who was indicted by UN serious crimes investigators for his role in the Suai Church Massacre in 1999 and charged with crimes against humanity. Bere, who had been living beyond the court's jurisdiction in West Timor since 1999, sought, in 2009, to return to his community to attend a family funeral. Some reports suggested that, after being recognised by members of his local community, he was detained and beaten before being handed over to the East Timorese police. Other, less prominent, examples of eviction have also occurred. For instance, a group of people who sought to return to their village in Same in 2014 was reportedly driven out of their community because of their connections to local militia groups.

These forms of 'rough justice' and social exclusion-which resonate with Mitchell's concept of threatworks - mesh uneasily with TimorLeste's national legal framework. ${ }^{58}$ Yet, in a context in which political decision-makers do not always adhere to the formal law, ${ }^{59}$ communities create their own forms of regulation that help to police the boundaries of community and keep perceived threats at bay. These everyday rules remain largely unspoken and are shifting and fluid. They are also imbued with the asymmetrical, hierarchical and gendered power relationships

56 International Crisis Group, Timor-Leste: Reconciliation and Return from Indonesia, 3.

57 Damaledo, 'From Refugee to Citizen', 24.

58 According to this framework, those who are the subject of an indictment order by UN serious crimes processes for their role in 1999-related serious crimes should be prosecuted by the Timorese courts.

59 In relation to Martinus Bere, for instance, soon after Bere's transfer to Becora prison to await trial, he was released back into Indonesian territory, following the intervention of the prime minister and president. This occurred on 30 August, the day of the tenth anniversary of the referendum. See CIGI, Security Sector Reform Monitor: Timor-Leste. 
of life in a kinship-based society. For instance, practices of eviction or inclusion appear to be based on a complex blend of factors that includes, among other things, local knowledge of a person's past 'mistakes' (in the form of violent crime or community betrayal), their perceived resistance credentials, and their relationships to others in the community, including their status. Those who are members of powerful families seem to have more community protection than those with less power, while those who are perceived to have played important roles in the resistance movement also appear to have significant social capital (even in cases where they have committed crimes). ${ }^{60}$

Another way in which people are negotiating the legacies of the conflict is through the subtle avoidance of, or silence about, certain conflictrelated topics. Two topics remain particularly sensitive and difficult to speak of in public life. One is the issue of East Timorese 'collaboration' with the Indonesian regime. The second is the issue of sexual violence against women. The experiences of women who, during the Indonesian occupation, were coerced into long-term sexual relationships with members of the Indonesian military raise the spectre of both kinds of 'unspeakability'. Not only were these women subjected to sexual violence but they are also perceived as collaborators due to becoming 'military wives'. These women's experiences also bring to the fore complex kinds of 'fatal knowledges'; specifically, they highlight the extent to which local leaders and women's own families were at times complicit in their 'marriages', sacrificing them in exchange for the security of the village or family. For all of these reasons, public discussion of their experiences remains taboo and some of these women have not spoken about this aspect of their pasts even to their own families and children. ${ }^{61}$

Viewing these women's silences through the lens of the everyday allows for a consideration of their multiple meanings. It also enables attention to the ways in which, at different times and in the context of different relational configurations, women might elevate one tactic over another.

60 To give two brief examples, I was informed by an observer of the same case that those who had sought to return were not members of a powerful liurai (royal) family and, as a consequence, had little community protection or support. By contrast, a community in Los Palos had seemingly reintegrated a militia member who, after having served a small portion of his 33-year jail sentence for crimes against humanity, had been pardoned. Part of the reason for the community's acceptance of this person seems to relate to high status and his resistance credentials; specifically, he had been involved in the FALINTIL resistance (before switching sides) and was also a member of a powerful liurai family.

61 See Kent, 'Narratives of Suffering and Endurance'. 
For instance, on one reading, it is possible to understand the women's silence as a consequence of ongoing structural violence and discrimination, which makes it difficult for them to speak for fear of shame, humiliation and ostracism. In this sense, it is a reflection of the women's limited social capital in a context where their survival is fundamentally dependent on the maintenance of reciprocal family and kinship relationships. On another reading, the women might be understood to be exercising a constrained form of agency. Their silence in certain social contexts enables them to fulfil their maternal obligations by building better lives for their children. It also helps them to protect their own reputations (and the reputations of other women), carve out a degree of social acceptability, and maintain essential social and political relationships with their extended kin. In this sense, it might be understood, at least in part, as a silence of 'civility' and a silence of 'pragmatism'. ${ }^{62}$ It is a form of everyday reconciliation that is partly informed by a shared recognition that speaking about the past might be counterproductive and possibly dangerous to themselves and others.

\section{Towards a more dynamic conception of hybrid transitional justice}

As the examples drawn from Timor-Leste suggest, attending to practices of everyday reconciliation might help to enrich scholarship on hybrid transitional justice in a number of ways. In the broadest sense, the value of the concept of the everyday-like the concept of hybridity-lies in its ability to bring about a reorientation of our analytical lens away from elite, institutions and one-size-fits-all formulas towards the ways in which communities are experimenting with ways of living together. While not suggesting that there is no place for prescriptive hybridity, a focus on the everyday helps to reveal that formal, institutional initiatives-with their limited time frames, mandates and geopolitical constraints upon their work - will go only so far towards responding to peoples' everyday needs and concerns. The contours of these concerns often revolve around the complex dynamics of building and sustaining relationships, ensuring economic survival, caring for family, maintaining some form of control over the quality of life and warding off perceived threats.

62 Kent, 'Sounds of Silence'. 
The lens of the everyday also allows for a shift away from the binary categories that infuse transitional justice discourse and practice, including the categories of victim and perpetrator. By attending to everyday negotiations and interactions, it becomes clear that these static identities break down and a more complex and fluid set of identities and social relationships emerges. I would go so far as to argue that engaging with these complexities is essential given the nature of modern conflict. It is no longer possible, in many conflicts, to disentangle the 'home front' from the 'war front'. Additionally, the impact of conflict is increasingly seen in the form of a low-level, ongoing, chronic form of violence. ${ }^{63}$ Because of this, many people are implicated in what Primo Levi has aptly termed a 'gray zone' of mutual betrayal and complicity. ${ }^{64}$ All of this means that a focus on the rigid dichotomies of civilians/combatants, victims/ perpetrators - and indeed conflict/peace - is increasingly untenable, and makes it imperative to consider how complex forms of 'fatal knowledge' complicate efforts to rebuild.

Attending to the everyday also highlights that efforts at reconciliation are ongoing. What emerges from the Timor-Leste context at least is that there is no straightforward rupture between the conflict and the postconflict period. For many East Timorese, the reality of postconflict life is marked as much by continuity as change, particularly when it comes to questions of structural violence, economic opportunities and 'fatal knowledges' of community betrayal. While tentative forms of closure and resolution may be possible, it seems that people remain engaged in a dialogue with the past rather than making a complete break with it. Through the lens of the everyday it is possible to move beyond a focus on resolution and to contextualise one-off 'events' (such as dispute resolution practices) within a broader context. This is a context in which people deploy a range of fluid, shifting practices and tactics in both formalised and less-formalised settings and within different kinds of relationships, and where an ultimate form of 'resolution' may not be imaginable.

There is of course a danger that the concept of the everyday, like the concept of hybridity, sets up its own set of binaries. For instance, the everyday is often associated with 'local' actors who operate in a different

63 See Turcot DiFruscia, 'Listening to Voices', 137-138.

64 Scheper-Hughes and Bourgois describe Levi's 'gray zone' as 'a morally ambiguous space of mutual betrayal and complicity with the enemy'. See Scheper-Hughes and Bourgois, 'Introduction', 10, discussing Primo Levi, The Drowned and the Saved. 
sphere from the national/international actors. Mitchell reminds us, however, that the everyday is not a 'level of human organization' but rather 'dimension of human experience'. ${ }^{65}$ In other words, a range of actorsboth 'local' and 'international'-engage in practices of worldbuilding. The spheres of the 'local' and the 'international' are, moreover, overlapping and co-constitutive. In relation to the Timor-Leste context, for instance, the everyday reconciliation tactics of ordinary Timorese are necessarily entangled with, and constrained by, broader structural and geopolitical dynamics. Local tactics of silence and inclusion/exclusion need to be understood as a response, in part, to the impoverished possibilities of the globalised transitional justice template and the power dynamics that often infuse its practices. They speak, in part, to the unwillingness of powerful states to pursue the prosecution of senior members of the Indonesian military and the efforts of the Timorese Government, in this context, to pursue a strong relationship with its former occupier and powerful neighbour. ${ }^{66}$

Moreover, as the examples drawn from Timor-Leste bear out, the everyday is marked by deep ambiguities. It should not be romanticised or viewed as a repository of shared values. While the everyday provides a source of meaning, security and belonging for many people, it is also a site where violence is enacted, and inequalities and hierarchies reinforced. This violence is not only imposed by powerful outside forces, but is reproduced within communities, whose members are inevitably configured in asymmetrical relations of power with one another. All of this means that, just as questions are asked about the normative assumptions of, and power dynamics underpinning, liberal transitional justice discourse, they also need to be asked about the everyday. For instance, whose version of everyday reconciliation is being imagined? Whose interests does it serve? What practices of power does it disguise? ${ }^{27}$

Finally and relatedly, while there is an emphasis in the peacebuilding literature on the everyday as a site of creativity, resistance and potentially, of emancipation, the everyday emerging from the brief examples drawn

65 Mitchell, 'Quality/Control', 1625.

66 They also underscore the limitations of a focus on 'victims' and 'perpetrators'. Not only has this focus been unable to attend to complex legacies of betrayal and distrust, but it has neglected the broader injustices of occupation and exploitation that continue to have ramifications in peoples' everyday lives.

67 Williams, 'Reproducing Everyday Peace in North India', 245, puts forward these questions in regard to everyday peace. 
from Timor-Leste speaks more to the ways in which those with limited power 'make do' with the resources, tactics and possibilities at hand. De Certeau's distinction between 'strategies' and 'tactics' is salient here, as it is a reminder of the degree to which impoverished communities have limited scope to engage in long-term planning for their lives and, because of this, tend to 'navigate the everyday tactically rather than strategically. ${ }^{68}$ This is not to suggest that agency and creativity is absent, but to recognise that the tactics, actions and practices in which people engage are often immediately responsive to the context at hand. They have a fluid, shifting quality, may not be planned or organised, and cannot necessarily be predicted in advance. All of this seems to call for peacebuilding and transitional justice scholars to develop more nuanced and complex conceptions of human agency that go beyond a focus on creativity and resistance. ${ }^{69}$

\section{Conclusion}

Studying the everyday raises thorny methodological, ethical and practical challenges. Without wishing to minimise these, what I hope to have established here is simply that more attention is needed to the range of successful and less successful ways in which people seek to rebuild their everyday lives in the aftermath of protracted conflict. Insufficient attention is currently given to these complexities within analyses of hybridity in the transitional justice literature. What I find useful about the concept of the everyday is that it provides a critical tool with which to examine the unique, diverse and unexpected nature of everyday tactics while also making visible the broader geopolitical context, the power dynamics at different scales and the patterns of inequality that inevitably shape and constrain those tactics. Perhaps more so than the concept of hybridity, the everyday also helps make a shift beyond formal, institutional spheres towards a focus on the ways in which ordinary citizens in conflict-affected societies navigate and negotiate the realities of life. ${ }^{70}$ In essence, what I am arguing is for transitional justice scholars to embrace a rich, fluid and relational conception of hybridity, one in which the everyday occupies a central place.

68 Ross, Raw Life, New Hope, 124.

69 I borrow this idea from Veena Das. See Turcot DiFruscia, 'Listening to Voices', 138.

70 Mac Ginty, 'Everyday Peace', 550. 
This text is taken from Hybridity on the Ground in Peacebuilding and Development: Critical Conversations, edited by Joanne Wallis, Lia Kent, Miranda Forsyth, Sinclair Dinnen and Srinjoy Bose, published 2018 by ANU Press, The Australian National University, Canberra, Australia.

doi.org/10.22459/HGPD.03.2018.09 